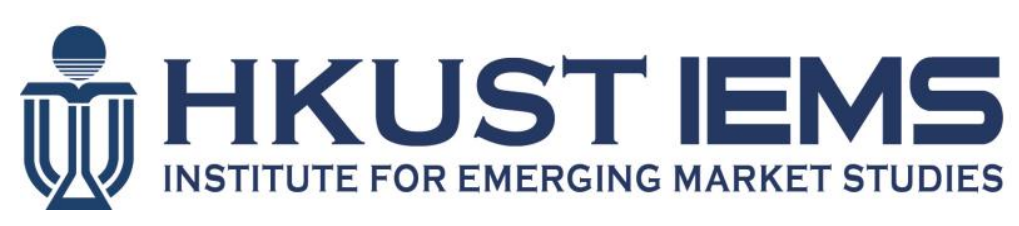

\title{
Magnet High Schools and Academic Performance in China: A Regression Discontinuity Design
}

\author{
Albert PARK, Xinzheng SHI, Chang-tai HSIEH, Xuehui AN
}

HKUST IEMS Working Paper No. 2015-07

February 2015

\begin{abstract}
HKUST IEMS working papers are distributed for discussion and comment purposes. The views expressed in these papers are those of the authors and do not necessarily represent the views of HKUST IEMS.
\end{abstract}

More HKUST IEMS working papers are available at: http://iems.ust.hk/WP 


\title{
Magnet High Schools and Academic Performance in China: A Regression Discontinuity Design
}

Albert PARK, Xingzheng SHI, Chang-tai HSIEH, Xuehui AN

HKUST IEMS Working Paper No. 2015-07

February 2015

\begin{abstract}
This paper investigates the impact of high school quality on students' educational attainment using a regression discontinuity research design based on entrance examination score thresholds that strictly determine admission to the best high schools. Using data from rural counties in Western China, we find that attending a magnet school significantly increases students' college entrance examination scores and the probability of being admitted to college.
\end{abstract}

\section{Author's contact information}

Albert Park

HKUST Institute for Emerging Market Studies, Division of Social Science, and Department of Economics

The Hong Kong University of Science and Technology

T : +852 23585981

E: albertpark@ust.hk

Xinzheng Shi

School of Economics and Management

Tsinghua University

E: shixzh@sem.tsinghua.edu.cn

Xuehui An

National Center for Education Development Research

China Ministry of Education 


\footnotetext{
* Correspondence author: Xinzheng Shi, shixzh@sem.tsinghua.edu.cn. Other email addresses: albertpark@ust.hk, chsieh@chicagobooth.edu, anxuehui@gmail.com. A previous version of this paper was titled "Does School Quality Matter?: Evidence from a Natural Experiment in Rural China." The authors thank seminar participants at Oxford, the University of Michigan, and Peking University for helpful comments. They acknowledge grants to support data collection from the University of Michigan Population Studies Center, NIH/Fogharty International Center, and the Economics Department of the University of California at Berkeley. IRB approval was obtained. Xinzheng Shi acknowledges the financial support from the National Natural Science Foundation of China (Project ID: 71103108). All remaining errors are ours.
} 


\section{Introduction}

Ability tracking, a practice that originated in developed countries (Figlio and Page, 2002), is now commonly observed in developing countries, including China. ${ }^{1}$ In China, middle school graduates often are tracked into magnet or regular high schools based on their academic ability as measured by high school entrance examination scores. Magnet high schools teach students the same curriculum as regular schools but typically have better teachers supported by greater resources, as well as more talented peers.

Studying the effect of magnet high school attendance on educational performance is important because it helps to answer a fundamental question in the economics of education: to what extent does attending a better school affect educational attainment? The answer to this question is of great interest to policymakers in developing countries, who often must make trade-offs between improvements in educational quality and the expansion of access to education when budgetary resources are scarce.

Theoretically, the effect of attending magnet schools on students is ambiguous. On the one hand, grouping students on the basis of their test scores means that magnet schools have more academically capable students than regular schools, which can improve students' performance through peer effects. In addition to direct knowledge spillovers among students, for teachers, having high-achieving students means less time spent on discipline and more time spent on knowledge transmission. ${ }^{2}$ On the other hand, attending better schools could affect different students differently. As shown in Duflo,

\footnotetext{
${ }^{1}$ Other developing countries in which such a trend can be seen include, but are not limited to, Kenya, Malawi, Colombia, Romania, and India (Duflo, Dupas, and Kremer, 2011; Lucas and Mbiti, forthcoming; de Hoop, 2010; Saavedra, 2009; Pop-Eleches and Urquiola, 2013; Rubinstein and Sekhri, 2010).

${ }^{2}$ A recent study by Ding and Lehrer (2007) carried out in a Chinese county produced strong evidence of positive peer effects. Other studies in this arena include Hoxby (2000), Zimmerman (2003), Angrist and Lang (2004), and Duflo, Dupas, and Kremer (2011). Epple and Romano (2011) provide a detailed review.
} 
Dupas, and Kremer (2011), if students are far from the ability level being targeted by instruction in magnet schools, attending a magnet school could have a negative effect on academic performance. Students who are relatively poor performers in a better school may have less confidence and receive less attention than better performers in lower quality schools. Thus, the effect of magnet schools on the students is not clear and requires empirical study.

In this paper, we quantify the impact of magnet high school attendance on students' educational attainment by exploiting the fact that in many of China's rural counties admission to the best high schools is strictly determined by entrance examination scores. In China, many rural counties operate a magnet school system for high schools. Typically, a rural county has one academically selective magnet high school as well as a number of regular (less selective) high schools. Nearly all students resident in a given county attend one of the county's middle schools. Graduating middle school students must take countywide uniform high school entrance examinations, which determine whether they are eligible to attend the magnet high school, a regular high school, or no high school at all. In any given county, the magnet school is usually widely viewed to have the best quality and has the highest entrance examination score cutoff line. ${ }^{3}$

We compare students in the same county with nearly identical entrance scores who attend different quality schools because they are just above or just below the cutoff score for admission to the magnet school. Our main outcome measure is scores on the national college entrance examination taken at the end of high school. Using information on the cutoff lines for college admission, we can also examine whether attending a magnet

\footnotetext{
${ }^{3}$ After graduating from middle school, students take the high school entrance examination. Magnet high schools admit students starting from highest score until they fill their admissions quota. The cutoff line is the lowest score among the students admitted.
} 


\footnotetext{
${ }^{4}$ de Hoop (2010) does find a positive impact on school participation in Malawi.

${ }^{5}$ Saavedra (2009) finds that attending an elite university in Columbia increases college exit examination scores and Rubinstein and Sekhri (2010) find no evidence of better learning in public (more selective) universities compared to private (less selective) universities in India. Duflo, Dupas, and Kremer (2011) find no impacts on test scores of attending selective classes in primary schools in Kenya, and Ma and Shi (2014) find positive impacts of attending magnet classes within a selective high school in China.
} 
qualifying for selective schools, which may differ across different settings. Studies of elite high schools in New York and Boston examine impacts on students who are quite accomplished (only about $10 \%$ qualify for selective schools). In such settings, regular high schools and student's families may have sufficient capacity to enable students to realize their full potential even if the student does not attend a more selective school. In Africa and many other developing countries, families are much poorer, parents are much less educated, schools struggle to effectively teach students, and learning outcomes are poor. In our context, evidence of large positive impacts on learning in a poor region of China, akin to a developing country, contrasts sharply with the results found in African countries and thus makes a valuable contribution to the literature. Although family resources and parental education also are lacking in our setting, in China and other Asian countries, families put great emphasis on education and schools perform well, sometimes spectacularly as seen in Shanghai's topping the global PISA rankings.

Our paper is also related to other studies that use different strategies to estimate the impact of different dimensions of school quality on students' performance. ${ }^{6}$ On China, our results are consistent with those of Ding and Lehrer (2007), who find that attending high schools with higher ability peers and better teachers increases college entrance examination scores using data from one county in a rich province (Jiangsu). ${ }^{7}$ Two other studies exploit natural experiments associated with admissions lotteries to examine the

\footnotetext{
${ }^{6}$ These strategies include comparison with matched control groups (Angrist and Lavy, 2001; Rockoff, 2004; Rivkin, Hanushek and Kain, 2005), randomized trials to examine the impact of specific schooling inputs, educational grants, or teacher incentive schemes (Dee, 2004; Banerjee, et.al., 2007; Glewwe, Kremer and Moulin, 2009; Muralidharan and Sundararaman, 2011; Duflo, Hanna, and Ryan, 2012), and natural experiments that create plausibly exogenous variation in class size (Angrist and Lavy, 1999; Hoxby, 2000) or in the quality of schools attended, e.g., lotteries (Gould, Lavy and Paserman, 2004; Hoxby, Murarka, and Kang, 2009).

${ }^{7}$ They do not employ an RD design but control for selectivity by instrumenting for elite school attendance with the estimated probability of such placement as a function of entrance examination scores and other factors.
} 
impact of attending higher quality middle schools in China, finding mixed results (Zhang, 2013; Lai, Sadoulet and de Janvry, 2011). ${ }^{8}$ Using a randomized trial in primary schools in China, Li, et. al. (2014) find that pairing high and low achieving students and offering them group incentives can increase low achiever's performance.

The rest of the paper is organized as follows. Section 2 introduces the institutional backgrounds. Section 3 describes the data and variable definitions. Section 4 presents the methodology for implementing the RD design and describes the empirical specification. Section 5 describes students' assignment to different schools in the sample used for analysis. This section also presents the results of tests of the continuity of covariates. Section 6 presents the main empirical results. Section 7 extends the analysis in several directions, and Section 8 concludes.

\section{Institutional backgrounds}

\subsection{Magnet high school system}

China's pre-college education system includes 6 years of primary school, 3 years of middle school, and 3 years of high school. Nearly all schools are public schools, especially in poor, rural regions; and public schools enjoy a much stronger quality reputation than private schools. ${ }^{9}$ In China, most counties operate a magnet school system for public high schools. Typically, a county has one academically selective magnet high school as well as a number of regular (less selective) high schools. Middle school graduates are obligated to take an entrance examination before they can be admitted to

\footnotetext{
${ }^{8}$ Zhang (2009) finds no impact of attending selective middle schools on high school entrance examination scores, while Lai, Sadoulet and de Janvry (2011) find a positive effect on high school entrance examination scores in a district in Beijing but mainly for lower ability students.

${ }^{9} \mathrm{We}$ did not find any private schools in the four counties that are examined in this study.
} 


\footnotetext{
${ }^{10}$ In 2004, the share of middle school graduates who went to high school in Gansu (not including vocational schools) was 47 percent, compared to 39 percent for all of China based on data from Ministry of Education (2005). In general, middle school graduates can be admitted only to high schools located within the county or district in which they reside. A few elite students may qualify for outstanding high schools in the municipal or provincial capital cities, and some students may attend high schools in other counties or districts if their parents move or have special connections.

${ }^{11}$ Required high school tuition and other fees are set by schools with the approval of county Education Bureaus, and may be more expensive for magnet high schools compared to regular high schools. Many schools provide limited scholarships for students from poor families.
} 
on a variety of quality indicators. ${ }^{12}$ Table 1 presents the results of simple regressions of school quality indicators on a dummy variable for whether the school is a magnet school and county-year fixed effects, as well as sample means for regular high schools. All of the differences are statistically significant. In magnet schools, the share of teachers with highest quality ranks, which are based on annual teaching evaluations throughout a teacher's career, is 0.10 greater than in regular schools, which have a mean share of only 0.07 (column 1$).{ }^{13}$ Teacher quality ranks have been found to strongly predict differences in student test scores (Hannum and Park, 2001). The share of teachers with four-year college education is 0.42 greater in magnet schools than in regular schools, whose share is only 0.34 (column 2). Class size in magnet schools is greater by about 9 students, or 17 percent (column 3). Magnet schools have 852 more students (or 111 percent) than regular schools, are larger in area by 52 thousand square meters (208 percent), have 67,720 more library books (1026 percent), and are 52.6 percentage points more likely to meet national criteria for adequate school facilities (only 32 percent of regular schools meet this standard). Thus, magnet schools are superior to regular high schools for a host of observable quality indicators.

\subsection{College admission}

In order to be admitted to colleges, Chinese high school graduates are required to take the nationally standardized College Entrance Examination (CEE). The total CEE

\footnotetext{
${ }^{12}$ Using annual data on schools collected from questionnaires, we measure school quality for each class by 4-year average values of school indicators that span the years that the class attended the school. For example, for students starting high school in September 1997 and graduating in June 2000, we take mean values for the years 1997 to 2000 .

${ }^{13}$ There are three levels of quality ranks for high school teachers in China: from lowest to highest, a second degree title, first degree title, and advanced title. These titles are awarded primarily on the basis of the educational degrees that teachers have obtained and their number of years of teaching experience. Additionally, there are several requirements regarding their teaching achievements.
} 


\footnotetext{
${ }^{14}$ Applicants to some special programs are screened by additional criteria: some art departments (e.g., audition), military and police schools (political screening and physical exam), and some sports programs (tryout).

${ }^{15}$ Most provinces use an admission procedure similar to the Boston Mechanism. In the first round, each college considers only students who list it as their first choice. Students with scores above a threshold score are accepted and the rest are rejected and placed in a pool of candidates for to be considered by the college next on students' lists of preferences. Only if there are remaining slots after the first round will a college consider admitting students who list it as their second or third choice. Once a college offers admission to a student, the selection process ends and the students are not considered by any other colleges.
} 


\footnotetext{
${ }^{16}$ Gansu has 86 counties. Data was not available for all years in each county due to differences in the quality of record keeping in different schools and counties.

${ }^{17}$ Calculated from county data on GDP and population reported in Gansu Bureau of Statistics (2004).

${ }^{18}$ Among the 9 counties with suitable data, the four counties that enforce the cutoff line are ranked 1, 2, 5, and 8 in terms of GDP per capita.
} 
Given our sample selection criteria, strictly speaking our estimates capture the impact of attending magnet schools in counties that strictly enforce entrance examination score cutoff lines. If enforcement of the cutoff line in a given county is endogenous to the quality difference between magnet and regular schools, our estimates are likely to be upper bound estimates for the impact of attending magnet schools in counties that did not strictly enforce the cutoff lines. However, analysis of the school data does not provide any evidence that the observable quality differences between magnet and regular high schools is different in counties that do and do not enforce the cutoff lines. We regress different measures of school quality on a magnet school dummy and the interaction of the magnet school dummy and a dummy indicating counties having binding cutoff line after controlling for county-year fixed effects. ${ }^{19}$ Results are presented in Appendix Table 1. None of the coefficients on the interaction terms are statistically significant, which suggests that the magnet-regular school quality difference does not differ significantly between counties having binding cutoff lines and those without binding cutoff lines.

We observe the high school entrance examination score for nearly 100 percent of students in the sample but only for 62 percent of those with high school entrance examination scores do we have data on the student's college entrance examination score. ${ }^{20}$ Missing data on college entrance examination scores can be due to multiple reasons: the student could have dropped out or transferred to another school, or decided not to sit for the college entrance examination; or the school could have kept incomplete

\footnotetext{
${ }^{19}$ As in Section 2.1, we measure school quality for an entering class by the 4-year average values of school indicators that span the years that they attended the school. For example, for students starting high school in September 1997 and graduating in June 2000, we take mean values for the years 1997 to 2000.

${ }^{20}$ The sample includes all students beginning high school in each year; students transferring into the high school after the first year are excluded but such transfers are relatively rare. The sample excludes students who take the high school entrance examination but do not attend high school; however, because nearly all students who get into any high school choose to enroll, this is unlikely to create sample selection bias among students whose entrance scores are near the cutoff lines for entering magnet high schools.
} 
records. In one school we visited, college entrance examination scores had been kept only for those who had scored high enough to enter college. One concern that arises with missing college examination scores is that our estimates of the impact of attending a magnet school on college examination scores could suffer from bias caused by differences in the selectivity of who have college entrance examination scores in magnet schools and in regular schools. However, our estimate results show that for students around the cutoff line whether they attend magnet schools or regular schools does not have a statistically significant impact on their probability of having a college entrance examination score (see Section 7.1), suggesting that such selection bias is not likely to be a major concern. ${ }^{21}$ In this paper, we focus on 5373 students having college entrance examination scores.

The survey collected school administrative data on students' gender, birth year, year of high school entrance, high school entrance examination score, and college entrance examination score. The survey also collected data from schools on the high school entrance examination score cutoff line and school characteristics such as teachers' educational attainment and the availability and quality of different types of school facilities.

Two treatment variables are defined. The variable magnet is assigned to equal one if the student actually attended a magnet school. The other treatment variable eligible is assigned to equal one if the student's high school entrance score was higher than the high school entrance examination cutoff line of the magnet school. While magnet more accurately reflects whether students actually attended better schools, it is subject to

\footnotetext{
${ }^{21}$ In supplementary regressions (not reported), we also find that the relationship between high school examination scores and having the college entrance examination score is not significantly different in magnet and regular high schools.
} 
selection bias if eligible students did not attend the magnet schools or ineligible students did attend the magnet school. Our preferred specification is one in which eligible is used as an instrumental variable (IV) for magnet.

The high school entrance examination scores and college entrance examination scores are the key variables used in the analysis. Scores are normalized to be equal to the number of standard deviations from mean scores of students taking the same examination. Specifically, define the normalized high school entrance examination score as follows:

$$
\widehat{H S}_{i j t}=\frac{H S_{i j t}-\overline{H S}_{j t}}{H S S D_{j t}} .
$$

Here, $H S_{i j t}$ is the high school entrance examination score for student $i$ in county $j$ who entered high school in year $t, \overline{H S}_{j t}$ is the mean high school entrance examination score for students in county $j$ who entered high school in year $t$, and $H S S D_{j t}$ is the standard deviation of high school entrance examination scores among students in county $j$ who began high school in year $t$.

College entrance examination scores are similarly defined in equation (2):

$$
\widehat{C S}_{i p t}=\frac{C S_{i p t}-\overline{C S}_{p t}}{C S S D_{p t}}
$$

The only difference is that the subscript $j$ is replaced with subscript $p$ for the college examination type, which in China can be liberal arts, natural science, physical education, musical education, or arts education. College entrance examinations differ from high school examinations in two respects: they are nationally standardized and they are specialized by subject area. Thus, $C S_{\text {ipt }}$ is the college entrance examination score for student $i$ entering high school in year $t$ taking test in subject $p$. 


\section{Methodology}

We employ an RD design to quantify the impact of school quality on educational attainment. First developed by Thistlethwaite and Campbell (1960), in recent years there has been an explosion of interest in applying RD design to a range of empirical questions

\footnotetext{
${ }^{22}$ The cutoff lines from different provinces come from http://www.eol.cn/include/cer.net/gaokao/zhuanti/2006_fenshuxian.shtml\#2000. There are different lowest cutoff lines for different types of college entrance examinations.

${ }^{23}$ In Gansu Province, the share of students having college entrance examination scores higher than the lowest cutoff lines who enroll in colleges are $94 \%$ in $2000,94 \%$ in $2001,92 \%$ in 2002 , and $93 \%$ in 2003 . These numbers are calculated from college entrance examination data files (2000-2003) provided by the Economic and Social Data Center in Tsinghua University.
} 
(see Lee and Lemieux (2010) for a review), and methodological best practice has evolved rapidly (Hahn, Todd, and van der Klaauw, 2001; Porter, 2003; Imbens and Lemieux, 2008; Lee and Lemieux, 2010).

We start with the basic regression model:

$$
Y_{i}=\beta+\alpha T_{i}+u_{i}, \text { where } T_{i}=1\left\{S_{i} \geq \bar{S}\right\}
$$

Here, $Y_{i}$ is the outcome variable, and $T_{i}$ is the treatment variable, which equals one if treated and zero otherwise. Those whose high school entrance examination score $S_{i}$ falls below some distinct cutoff point $\bar{S}$ are placed in the control group $\left(T_{i}=0\right)$, whereas those on or above the cutoff are placed in the treatment group $\left(T_{i}=1\right)$.

Under the assumption that the conditional mean function $\mathrm{E}[\mathrm{u} \mid \mathrm{S}]$ is continuous at $\bar{S}$, the treatment effect $\alpha$ can be identified as follows:

$$
\alpha=\lim _{S \downarrow \bar{S}} E[Y \mid S]-\lim _{S \uparrow \bar{S}} E[Y \mid S]
$$

Intuitively, the treatment effects are identified by the sample of individuals within a small interval around the cutoff point. Since these individuals have essentially the same $S_{i}$ value, we can expect individuals just below the cutoff line on average to be very similar to individuals just above the cutoff line and thus to have similar average characteristics regardless of treatment status, thus providing credible estimates of the true treatment effect.

One approach is to estimate $\alpha$ using non-parametric methods and a small range of data around the cutoff line. Another approach is to assume that $\mathrm{E}[\mathrm{u} \mid \mathrm{T}, \mathrm{S}]$ can be represented by a (low-order) polynomial function of $\mathrm{S}$, and use a wider range of data around the cutoff line (Lee and Lemieux, 2010). These two methods are equivalent if 
kernel regression methods and a rectangular kernel are used in the non-parametric method. Our paper follows the second method. The following equation is estimated:

$$
Y_{i}=\beta+\alpha T_{i}+k\left(S_{i}\right)+\omega_{i}
$$

As long as $k\left(S_{i}\right)$ is continuous in $S_{i}$, identification is achieved because of the discontinuity in the function $T\left(S_{i}\right)$. As pointed out by Lee and Lemieux (2010), the spirit of $\mathrm{RD}$ design is to compare the conditional expectation of $\mathrm{Y}$ at the cutoff approaching from the left with the conditional expectation of $\mathrm{Y}$ at the cutoff approaching from the right, which implies that slope of the lines at the cutoff could be different. We therefore define $k\left(S_{i}\right)=k_{L}\left(S_{i}-\bar{S}\right)+T_{i} *\left(\left(k_{R}\left(S_{i}-\bar{S}\right)-k_{L}\left(S_{i}-\bar{S}\right)\right)\right.$, where L indicates the left of the cutoff while $\mathrm{R}$ indicates the right of the cutoff. This formulation normalizes $S_{i}$ by the cutoff line and allows the continuous function of $\mathrm{S}$ to have a different shape to the right of the cutoff than to the left of the cutoff. In practice, we approximate $k_{R}$ and $k_{L}$ using polynomial functions whose order is determined by the AIC. ${ }^{24}$ To address the potential concerns that the probabilities of students having the same high school entrance examination score being admitted to magnet schools are correlated within counties and that the high school entrance examination score is discrete, we cluster the standard errors at the county-high school entrance examination score level (Lee and Card, 2008, and Dobbie and Fryer, forthcoming).

A key specification issue in estimating (5) is selection of an appropriate bandwidth, or range of observations around the cutoff, to be used in the regressions. On the one hand, a wider bandwidth increases the sample size and so increases the power of the regression; on the other hand, it allows students with scores increasingly far from the cutoff to

\footnotetext{
${ }^{24}$ The detailed summary statistics for AIC are not reported due to space limitations but are available from the authors upon request.
} 
influence the impact estimates, increasing potential bias. To choose an optimal bandwidth that balances these factors, we follow the cross-validation procedure suggested by Imbens and Lemieux (2008). ${ }^{25}$ The main idea is to predict outcome values by estimating nonparametric local linear regressions using a "leave one out" procedure for different possible bandwidths, and to choose the bandwidth that minimizes the mean square residuals for each regression specification. The method is carried out separately for observations on either side of the cutoff line. ${ }^{26}$

We conduct several tests of the assumptions that underpin the RD specification. Lee (2008) proposes a direct test of the continuity assumption by checking whether there are discontinuities in the relationship between the treatment effect and any predetermined covariates. That is, the following equation can be estimated:

$$
X_{i}=\delta+\varphi T_{i}+k\left(S_{i}\right)+\varepsilon_{i}
$$

If $\varphi$ is not statistically significant, then the continuity assumption is valid. We test for three predetermined covariates: gender, age, and the quality of middle school attended, which is measured by the average high school entrance examination score of students attending the same middle school in the same year. ${ }^{27}$

In the $\mathrm{RD}$ design, treatment depends on the selection variable $\mathrm{S}$ in a deterministic way. However, in reality, it is likely for treatment assignment to depend on $\mathrm{S}$ in a stochastic manner, which is referred to in the literature as fuzzy RD design. In our main sample, 11.7 percent of students not in magnet schools have high school entrance

\footnotetext{
${ }^{25}$ Please see Imbens and Lemieux (2008) or Lee and Lemieux (2010) for a detailed description of the cross-validation method. The method includes all of the covariates in the estimated models.

${ }^{26}$ Detailed summary statistics on mean square residuals are not reported due to space limitations but are available from the authors upon request.

${ }^{27}$ We should note that our measure of middle school quality is not perfect since we only collected information on students attending high schools; therefore, it is an upward biased estimate of the middle school quality.
} 
examination scores above the cutoff line, and 10.9 percent of students in magnet schools have high school entrance examination scores below the cutoff. ${ }^{28}$ In this case, the OLS estimate of $\alpha$ in equation (5) using the variable magnet could be subject to selection bias. This is where the second treatment variable eligible can help avoid the problems associated with bias caused by fuzzy RD design. The variable eligible itself does not suffer from fuzziness and so can be used to cleanly estimate an intent-to-treat effect. However, the impact of eligibility is not of primary interest. Our goal is to estimate the impact of actually attending better schools. To obtain an unbiased estimate of this effect, we can use eligible as an instrument for magnet, since eligible strongly predicts magnet but is not subject to selectivity bias. If we believe that the slope of the relationship between the outcome variables and the high school entrance examination score differs to the right and left of the cutoff because the relationship is different in magnet schools and regular schools, then one can capture this difference by interacting magnet with the polynomial terms of $\left(S_{i}-\bar{S}\right)$ and instrumenting these interactions with the interactions of eligible with the same polynomial terms. We note that, conditional on the validity of the IV, our estimates apply only to students complying with the assignment rule, for whom we identify a local average treatment effect (LATE).

\section{Student assignment and continuity of covariates}

\footnotetext{
${ }^{28}$ There are several possible reasons. One is that parents or teachers influence high school placement decisions using personal connections. Many schools even establish explicit systems to allow parents to pay extra fees to enable their children to attend their schools if their children's test scores are just below the cutoff, although the extent of such practice was limited during the time period covered by the data. In such systems, normally the amount of extra fees is a function of how far the student's entrance examination score is from the cutoff, with very poor students being excluded altogether because of the school's concern to maintain its quality reputation. On the contrary, some students having scores higher than the cutoff could decide not to attend magnet high schools because they cannot afford the tuition charged by magnet high schools or they live in remote villages such that the transportation costs are too high.
} 
Students are assigned to magnet schools and regular schools according to their high school entrance examination score. Figure 1 shows the distribution of students with different high school entrance scores in magnet and regular schools. In order to pool data from different county-years, we create a variable that indicates each student's score relative to the entrance cutoff score in each county-year, which is shown on the x-axis. Yaxis shows the share of students enrolled in the magnet school. We plot this share for students with entrance scores falling in equidistant bins, plotted against the midpoint of each bin. ${ }^{29}$ The figure highlights the fact that there is a sharp change in the probability of treatment close to the cutoff. However, Figure 1 also reveals that, in practice, the cutoff line is not adhered to in all cases; if it were, then the gap at the cutoff line would be equal to one. Because of this fuzziness in the implementation of cutoff lines, in the following analysis, our preferred results come from the regressions using eligible as an instrument for magnet.

We also conduct regressions to estimate the impact of eligible on magnet. Columns 1 and 2 in Table 3 use the sample consistent with that used in Figure 1, controlling only for first and second order polynomial functions of students' high school entrance examination score relative to the cutoff, respectively. Columns 3 and 4 correspond to the different samples used to explain the two outcome variables: the college entrance examination score and the probability of qualifying for college. Therefore, these two columns are also the first stage regression results for the main regressions (shown in Table 5). A female dummy, age, middle school fixed effects, county-year fixed effects,

\footnotetext{
${ }^{29}$ The bin size width used is 0.3 . For this figure and those reported afterwards, in order to ensure that the bin size width does not hide significant outcome differences within bins, we verify that the bin size passes a simple test in which bin dummies and interactions of bin dummies with the running variable $\left(S_{i}-\bar{S}\right)$ are included and the coefficients on the interaction terms are jointly statistically insignificant (Lee and Lemieux, 2010).
} 
and a first order polynomial function of students' high school entrance examination score relative to the cutoff are controlled for in columns 3 and 4. Table 3 shows that the coefficient of eligible is statistically significant at the $1 \%$ level in all columns. Depending on the specification, the results imply that having a high school entrance examination score just above the cutoff increases the probability of entering a magnet high school by 33.1 to 51.7 percentage points. The last row presents F-values for the null hypothesis that the coefficients of eligible and the interactions of eligible and polynomial terms of $\left(S_{i}-\bar{S}\right)$ are equal to zero. The F-values are 121.14 (column 3) and 111.59 (column 4). These results suggest that eligible is an extremely strong predictor of actually enrolling in a magnet school, justifying its use as an instrument.

Next, we report results for tests that examine whether the three predetermined covariates jump in a discontinuous fashion at the entrance examination cutoff line. In Figure 2, the $\mathrm{x}$-axis measures the difference between the high school entrance examination scores and the cutoff line for each county-year; the y-axis measures proportion of female students in Panel A, age in Panel B, and middle school quality (measured by the average high school entrance examination score of students attending the same middle school in the same year) in Panel C..$^{30}$ The samples used for Figure 2 are the same as those used in the regressions in Table 4, which are determined by the crossvalidation method described earlier. It is evident that for all three variables there is no jump at $\mathrm{x}=0$, the point at which the high school entrance examination score is equal to the cutoff line. This provides support for the validity of the RD design.

\footnotetext{
${ }^{30}$ We plot the mean values for students with entrance scores falling in equidistant bins, plotted against the midpoint of each bin. The bin size widths used in panels A, B and C are $0.08,0.08$, and 0.016 , respectively.
} 


\section{Impacts of attending a magnet high school on educational attainment}

Figure 3 plots the two outcome variables as a function of the high school entrance examination score relative to cutoff lines. In each figure, we plot the mean values of the outcome variables for students with entrance scores falling in equidistant bins, plotted against the midpoint of each bin. ${ }^{31}$ Panel $\mathrm{A}$ in Figure 3 plots the college entrance examination scores. One can see that at the cutoff $(x=0)$, there is a clear positive jump of about 0.4 standard deviations. Panel B plots college eligibility, and shows a jump at the cutoff line of about 0.2 (20 percentage points). These pictures provide visual estimates of the size of the treatment effects using the RD design, but do not control for covariates or a polynomial function of the running variable as is done in the regressions.

${ }^{31}$ The bin size width used is 0.06 in both Panel A and Panel B. 
Table 5 presents the estimates of the effects of entering a magnet school on a student's college entrance examination score and a student's probability of qualifying to enter college. For all outcome variables we present results using three treatment variables: magnet (columns 1 and 4), eligible (columns 2 and 5), and magnet using eligible as an IV (columns 3 and 6). In each column, we control for a female dummy, age, middle school fixed effects, county-year fixed effects, and a first order polynomial function of the high school entrance examination score relative to the cutoff. We report bandwidths on left and right chosen using the cross-validation procedure described by Imbens and Lemieux (2008). For example, $[-1.8,1.1]$ in column 1 means that only students having high school entrance examination scores greater than 1.8 standard deviations below the cutoff and less than 1.1 standard deviations above the cutoff are used in the estimation.

Columns 1 to 3 of Table 5 show the estimated impact on the college entrance examination score. The coefficient on magnet is 0.302 (column 1), the coefficient on eligible is 0.153 (column 2), and the coefficient on magnet using eligible as an IV is 0.387 (column 3 ). All three coefficients are significant at the $1 \%$ level. This suggests that attending a magnet school increases college entrance examination scores by 0.387 standard deviations.

Columns 4 to 6 of Table 5 show the estimated impact on the probability of qualifying to enter college. All of the coefficients on the treatment variables are statistically significant at the $1 \%$ level. The effect of magnet is 0.135 (column 4), the effect of eligible is 0.099 (column 5), and the IV estimate for magnet is 0.278 (column 6). Thus, according to our preferred IV estimate, attending a better high school increases the probability of qualifying for college entrance by 27.8 percentage points. 
The results presented in Table 5 are average impacts of school quality on students' educational attainment. However, the impacts might be different for different groups of students. To check this, we present the results of heterogeneity tests with respect to gender and age, with results presented in Table 6 . We continue to follow the same specifications as before but add an interaction term between the female dummy and the treatment variable (columns 1 and 2) and an interaction term between age and the treatment variable (columns 3 and 4), respectively. In Table 6, we only present the preferred IV estimates. We find that the coefficients of the interactions of magnet and the female dummy are equal to 0.003 and 0.074 in the regressions for college entrance examination scores and qualifying for college admission, respectively. Neither of them are statistically significant. Columns 3 and 4 report results on heterogeneous impacts with respect to age. All the coefficients on the interaction terms of magnet and age are statistically insignificant (with magnitudes -0.059 and -0.012 , respectively).

\section{Extensions}

\subsection{Impact of attending magnet high schools on the probability of observing a college entrance examination score}

As mentioned in Section 3, we observe 62 percent of students having college entrance examination scores. There is a concern that for students having high school entrance scores around the cutoff there are differences in the selectivity of who have college entrance examination scores in magnet schools and in regular schools such that the estimates of the impact of attending magnet schools on the college entrance examination scores would be biased. In this section, we check whether attending magnet 
high schools has any impacts on the probability to observe a college entrance examination score for students around the cutoff.

Table 7 presents estimates of the impact of entering a magnet school on whether a college examination score is observed. In all columns, we control for the female dummy, age, middle school fixed effects, county-year fixed effects, and a first order polynomial function of the high school entrance examination score relative to the cutoff line. Columns 1 and 2 use the same samples as those used for college entrance examination score (columns 1-3 in Table 5) and eligibility for college (columns 4-6 in Table 5), respectively. Column 3 uses the sample chosen by the method of cross-validation for the probability to observe a college entrance examination score. We only present the results using eligible as an IV for magnet. The coefficients of magnet are -0.022 (column 1), 0.020 (column 2) and -0.039 (column 3 ). None of the three coefficients are statistically significant. In supplementary regressions (not reported), we also find that the relationship between high school examination scores and having the college entrance examination score is not significantly different in magnet and regular high schools. These results suggest that selection problem is not likely to be a major concern.

\subsection{Impact of attending magnet high schools on students' course study}

In China, high school students can choose different courses of study, focusing on liberal arts, natural sciences, physical education, or musical education. The vast majority (97\% in our sample) choose either liberal arts or natural sciences. If entering magnet schools decreases the probability of students to choose liberal arts, which is generally viewed as less competitive than natural sciences, and it is harder for students studying 
natural sciences to earn a higher college entrance examination score, then our estimates of the impact of attending a magnet school on college entrance scores and college admissions probability could be biased downward.

To test whether this concern is likely to be important, we estimate the impact of entering a magnet school on the probability of choosing the liberal arts track, following the same specification as for other outcomes. The results are presented in Table 8. The dependent variable in this table is equal to one if the student takes the liberal arts track and zero otherwise. As in Section 7.1, columns 1 and 2 use the same samples as those used in estimating the determinants of college entrance examination score (columns 1-3 in Table 5) and eligibility for college (columns 4-6 in Table 5), respectively, while column 3 uses the sample chosen by the method of cross-validation for the probability to take the liberal arts track. We only present the results using eligible as an IV for magnet. The coefficients on magnet are -0.081 (column 1), -0.087 (column 2), and -0.068 (column 3). None of the three estimates are statistically significantly different from zero. Thus, overall there is no evidence that attending a magnet school significantly impacts students' courses of study.

\subsection{Robustness of main results to the sample used}

In the main analysis (Table 5), two different bandwidths (and therefore samples), chosen by the method of cross-validation, are used for college entrance examination scores $([-1.8,1.1])$ and eligibility for college $([-1.4,1.1])$, respectively. To check whether the estimated impacts of entering magnet high schools are robust to samples used, we firstly switch the samples used for these two outcome variables. That is, we use the 
bandwidth $[-1.4,1.1]$ for college entrance examination scores while we use the bandwidth $[-1.8,1.1]$ for eligibility for college. We then take the smallest endpoint of the above two bandwidths (i.e. 1.1) and use a symmetric bandwidth (i.e. [-1.1,1.1]) for both outcome variables. We use the same specifications as those in Table 5. The estimated results are shown in Table 9. We only present the estimated results using eligible as an IV for magnet.

The estimated impacts of attending magnet high schools are robust to different samples used. The outcome variables in columns 1 and 2 in Table 9 are college entrance examination scores. The bandwidth $[-1.4,1.1]$ is used in column 1 while the bandwidth [1.1,1.1] is used in column 2. We can see that the coefficients on magnet are 0.365 (column 1) and 0.355 (column 2). The former one is significant at the 5 percent level and the latter one is significant at the 10 percent level. These two coefficients are close to that (0.387) shown in column 3 in Table 5. The outcome variables in columns 3 and 4 are eligibility for college. The bandwidth $[-1.8,1.1]$ is used in column 3 while the bandwidth $[-1.1,1.1]$ is used in column 4 . We can see that the coefficients on magnet are 0.298 (column 3) and 0.279 (column 4). The former one is significant at the 1 percent level and the latter one is significant at the 5 percent level. These two coefficients are also close to that $(0.278)$ shown in column 6 in Table 5.

\subsection{Total effect of attending magnet high school}

As described in Section 3, 38 percent of students have missing college entrance examination scores. One important reason is that they did not take the college entrance examination. In this section, we assume that students with missing college entrance 
examination scores did not take the college entrance examination and therefore were not eligible for college. By doing so, we construct a new college eligibility variable. This variable is similar with that defined in the main analysis but includes students having missing college entrance examination scores, for whom the value of this new college eligibility variable is zero. Then, we estimate the effect of attending magnet high schools on this newly defined college eligibility variable. Table 10 shows the estimated results.

We use the same specification in Table 10 as that used in Table 5 and only present the estimates using eligible as an IV for magnet. The bandwidths used in columns 1 and 2 are the same as those used for college entrance examination scores (columns 1-3 in Table 5) and eligibility for college (columns 4-6 in Table 5), respectively. The bandwidth used in column 3 is chosen by the method of cross-validation for the newly defined college eligibility. We can see from Table 10 that the coefficients are $0.227,0.217$, and 0.217 in columns 1-3, respectively. All of them are significant at the one percent level. Compared with the coefficient (0.278) shown in column 6 in Table 5, the coefficients shown in Table 10 are similar but smaller, which could be due to the fact that attending magnet schools (insignificantly) reduces the probability to observe college entrance examination scores (shown in Table 7).

\section{Conclusion}

Whether school quality can improve students' educational attainment is an important and highly debated question in the economics of education. This paper uses China's magnet school system and the RD approach to credibly estimate the effects of higher high school quality on students' educational attainment. 
Using data from four counties in Gansu province in China, according to our preferred IV estimates, we find that for students whose high school entrance scores are near the cutoff line for being admitted to magnet schools, attending a magnet high school significantly increases students' college entrance scores by 0.387 standard deviations and increases the probability of qualifying for college by 27.8 percentage points.

These large positive impacts of attending magnet high schools in a poor, rural region of China are one of the only estimates for a low-income setting, and contrast sharply with the finding of no impacts of attending selective schools in African countries. These differences, along with mixed findings from other RD studies in other countries, highlight the likely importance of contextual factors in conditioning the impact of attending selective high schools. In rural Gansu, families have limited capability to support students in terms of both income and parental human capital, but schools general perform well and provide strong promotion incentives for teacher effort (Karachiwalla and Park, 2014). In this environment, attending schools with better teachers, peers, and infrastructure appears to make a difference.

Although RD analysis can help to resolve the problem of omitted variables, caution should be exercised in interpreting our findings. The RD analysis identifies the impact of attending magnet schools on students whose high school entrance scores are near the cutoff line. The impacts could be different for students at other parts of the distribution of high school entrance scores (better students and worse students). Also, because we use the IV approach to deal with fuzziness, our results can be interpreted as LATE, meaning that they can be applied only to students who complied with the admissions rule. 
1

2

Due to data limitations, we also cannot investigate the channels through which magnet high schools affect students' academic performance. Shedding greater light on this question in future research will yield deeper insights into the determinants of educational attainment and enable researchers to provide more specific policy implications. 


\section{References}

Abdulkadiroglu, Atila, Joshua D. Angrist, and Parag A. Pathak (2014).“The elite illusion: Achievement effects at Boston and New York exam schools," Econometrica, Vol. 82, No.1: 137-196.

Ajayi, Kehinde F. (2014), "Does School Quality Improve Student Performance? New Evidence from Ghana", mimeo.

Angrist, Joshua D., and Kevin Lang (2004). Does school integration generate peer effects? Evidence from Boston's Metco Program, American Economic Review, 94(5): 1613-1634.

Angrist, Joshua D. and Victor Lavy (1999)."Using Maimonides' rule to estimate the effect of class size on scholastic achievement," The Quarterly Journal of Economics, Vol. 114 , No. 2, 533- 575.

Angrist, Joshua D. and Victor Lavy (2001). "Does teacher training affect pupil learning? Evidence from matched comparisons in Jerusalem public schools," Journal of Labor Economics, Vol. 19, No. 2, 343-369.

Banerjee, Abhijit V., Shawn Cole, Esther Duflo, and Leigh Linden (2007). "Remedying education: Evidence from two randomized experiments in India," The Quarterly Journal of Economics, Vol. 122, No, 3, 1235-1264.

Bui, Sa A., Steven G. Craig, and Scott A. Imberman. (forthcoming). "Is gifted education a bright idea? Assessing the impact of Gifted and Talented programs on Students," American Economic Journal-Economic Policy.

Clark, Damon (2010). "Selective Schools and Academic Achievement," The B.E. Journal of Economic Analysis \& Policy, Vol. 10, No. 1 (Advances), Article 9.

Dee, Thomas S. (2004). "Teachers, race and student achievement in a randomized experiment," The Review of Economics and Statistics, Vol. 86, No.1, 195-210.

de Hoop, Jacobus. (2010). "Selective Secondary Education and School Participation in Sub-Saharan Africa: Evidence from Malawi," Discussion Paper 2010-041/2, Tinbergen Institute.

Ding, Weili, and Steven F. Lehrer (2007). "Do Peers Affect Student Achievement in China's Secondary Schools?," The Review of Economics and Statistics, Vol.89, No. $2,300-312$.

Dobbie, Will, and Roland Fryer (forthcoming). "The Impact of Attending a School with High-Achieving Peers: Evidence from the New York City Exam Schools,"American Economic Journal: Applied Economics. 
Duflo, Esther, Pascaline Dupas, and Michael Kremer (2011)."Peer Effects, Teacher Incentives, and the Impact of Tracking: Evidence from a randomized evaluation in Kenya," American Economic Review, Vol. 101, No. 5,1739-74.

Duflo, Esther, Rema Hanna, and Stephen P. Ryan (2012)."Incentives Work: Getting Teachers to Come to School”, American Economic Review, Vol. 102, No. 4, 1241-1278.

Epple, Dennis, and Ricard Romano (2011). Peer effects in education: A survey of the theory and evidence. Handbook of Social Economics, 1(11): 1053-1163.

Figlio, David, and Marianne Page (2002). School choice and the distributional effects of ability tracking: Does separation increase inequality?, Journal of Urban Economics, 51: 497-514.

Gansu Bureau of Statistics (2004). Gansu Statistical Yearbook 2004 (Beijing: China Statistical Press).

Glewwe, Paul, Michael Kremer, and Sylvie Moulin (2009). "Many children left behind? Textbooks and test scores in Kenya," American Economic Journal: Applied Economics, Vol.1, No. 1, 112-135.

Gould, Eric D., Victor Lavy, and M. Daniele Paserman (2004). "Immigrating to opportunity: Estimating the effect of school quality using a natural experiment on Ethiopians in Israel," The Quarterly Journal of Economics, Vol. 119, No. 2, 489-526.

Hahn, Jingyong, Petra Todd, and Wilbert van der Klaauw (2001). "Identification and estimation of treatment effects with a regression-discontinuity design," Econometrica, Vol. 69, No. 1, 201-209.

Hannum Emily and Albert Park (2001). "Do teacher characteristics affect student learning in developing countries?: Evidence from matched teacher-student data from rural China", mimeo.

Hoxby, Caroline M. (2000). "The effects of class size on student achievement: New evidence from population variation," The Quarterly Journal of Economics, Vol. 115, No. 4, 1239-1285.

Hoxby, Caroline M., Sonali Murarka, and Jenny Kang (2009). "How New York City's Charter Schools Affect Achievement," Report for the New York City Charter Schools Evaluation Project.

Imbens, Guido W., and Thomas Lemieux(2008)."Regression Discontinuity Designs: A Guide to Practice," Journal of Econometrics, Vol. 142, No. 2, 615-635. 
Jackson, C. Kirabo (2010). "Do Students Benefit from Attending Better Schools?: Evidence from Rule-based Student Assignments in Trinidad and Tobago," The Economic Journal,120: 1399-1429.

Karachiwalla, Naureen, and Albert Park (2014). "Promotion Incentives in the Public Sector: Evidence from Chinese Schools", mimeo.

Lai, Fang, Elisabeth Sadoulet, and Alain de Janvry. (2011). "The contributions of school quality and teacher qualifications to student performance: Evidence from a natural experiment in Beijing middle school," Journal of Human Resources, Vol. 46, No.1, 123153.

Lee, David S. (2008). "Randomized experiments from non-random selection in U.S. House Elections," Journal of Econometrics, Vol. 142, 675-697.

Lee, David S., and Thomas Lemieux (2010)."Regression Discontinuity Design in Economics," Journal of Economic Literature, 48, 281-355.

Lee, David S., and David Card (2008). "Regression discontinuity inference with specification error," Journal of Econometrics, 142: 655-674.

Li, Tao, Li Han, Linxiu Zhang, and Scott Rozelle (2014). "Encouraging classroom peer interactions: Evidence from Chinese migrant schools," Journal of Public Economics, 111: $29-45$.

Lucas, Adrienne M, and Isaac M. Mbiti (forthcoming). "Effects of school quality on student achievement: Discontinuity evidence from Kenya," American Economic Journal: Applied Economics.

Ma, Mingming, and Xinzheng Shi (2014).“Magnet classes and educational performance: Evidence from China", Economic Development and Cultural Change, Vol. 62, No. 3, 537-566.

Ministry of Education (2005). China Education Statistics Yearbook 2005 (Beijing: People's Education Press).

Muralidharan, Karthik, and Venkatesh Sundararaman (2011). "Teacher Performance Pay: Experimental Evidence from India," Journal of Political Economy, Vol. 119, No. 1, 3977.

National Bureau of Statistics (2005). Chinese Statistical Yearbook.

Pop-Eleches, Christian, and Miguel Urquiola (2013). "Going to a Better School: Effects and Behavioral Responses," American Economic Review, Vol. 103, No. 4, 1289-1324.

Porter, Jack (2003). "Estimation in the regression discontinuity model," mimeo. 
Rivkin, Steven G., Eric A. Hanushek, and John F. Kain (2005).“Teachers, schools, and academic achievement," Econometrica, Vol. 73, No. 2, 417-458.

Rockoff, Jonah E. (2004)."The impact of individual teachers on student achievement: Evidence from panel data ," American Economic Review, Vol. 94, No. 2, 247-252.

Rubinstein, Yona, and Sheetal Sekhri (2010). "Do public colleges in developing countries provide better education than private ones? Evidence from general education sector in India," mimeo.

Saavedra, Juan Esteban. (2009). "The learning and early labor market effects of college quality: A regression discontinuity analysis," mimeo.

Thistlethwaite, Donald L. and Donald T. Campbell (1960)."Regression-discontinuity analysis: an alternative to the ex post facto experiment," Journal of Educational Psychology, Vol. 51, No. 6, 309-317.

Zhang, Hongliang (2013). "The mirage of elite schools: Evidence from lottery-based school admission in China," mimeo.

Zimmerman, David J. (2003). Peer effects in academic outcomes: Evidence from a natural experiment, The Review of Economics and Statistics, 85(1): 9-23. 
Figure 1 Student assignment

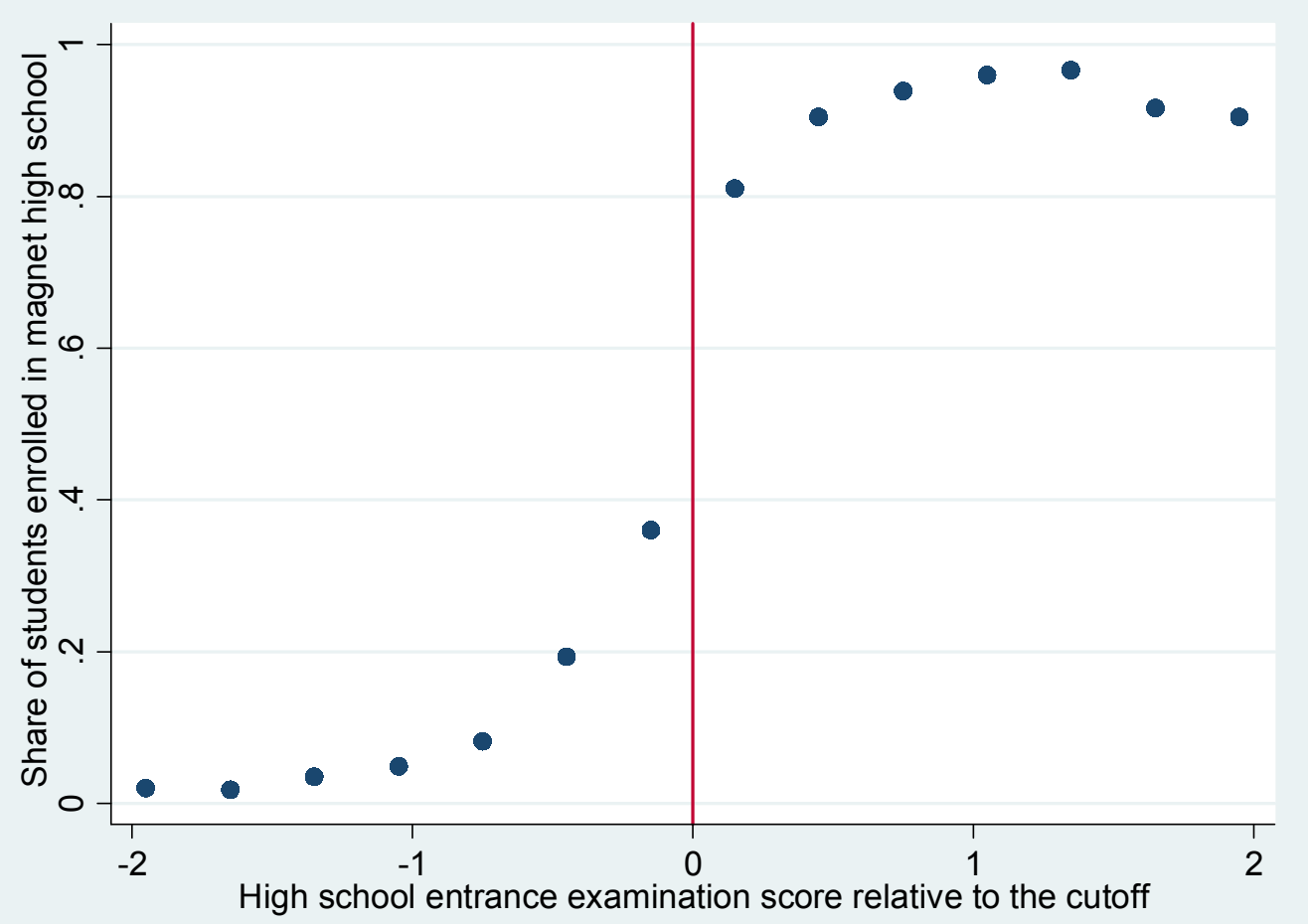

Note: (1) Dots in the graph are share of students enrolled in magnet high schools in equidistant bins with the width equal to 0.3. The dots are plotted against the midpoint of each bin. 
Figure 2 Tests of continuity of covariates

Panel A Gender

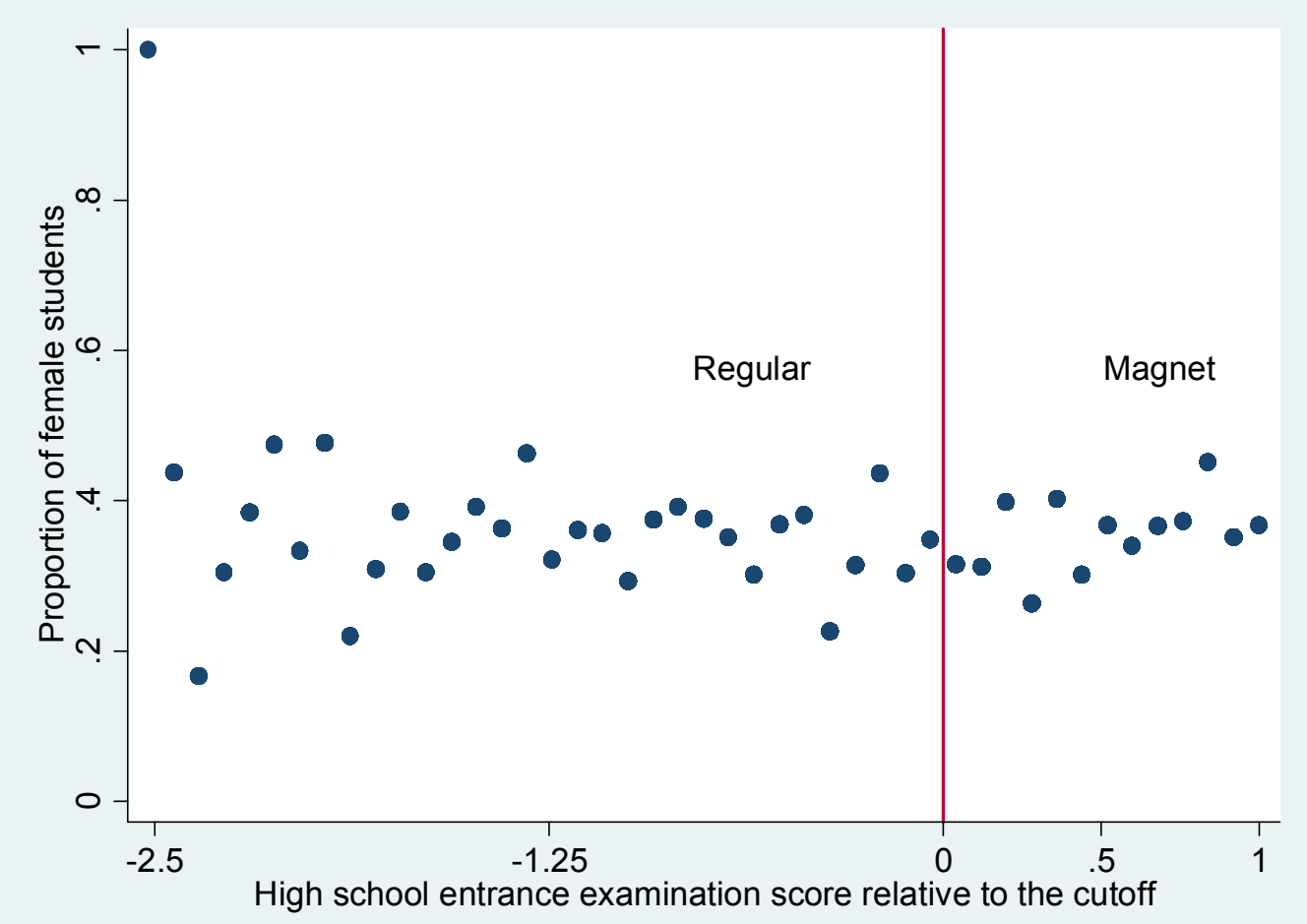

Panel B Age

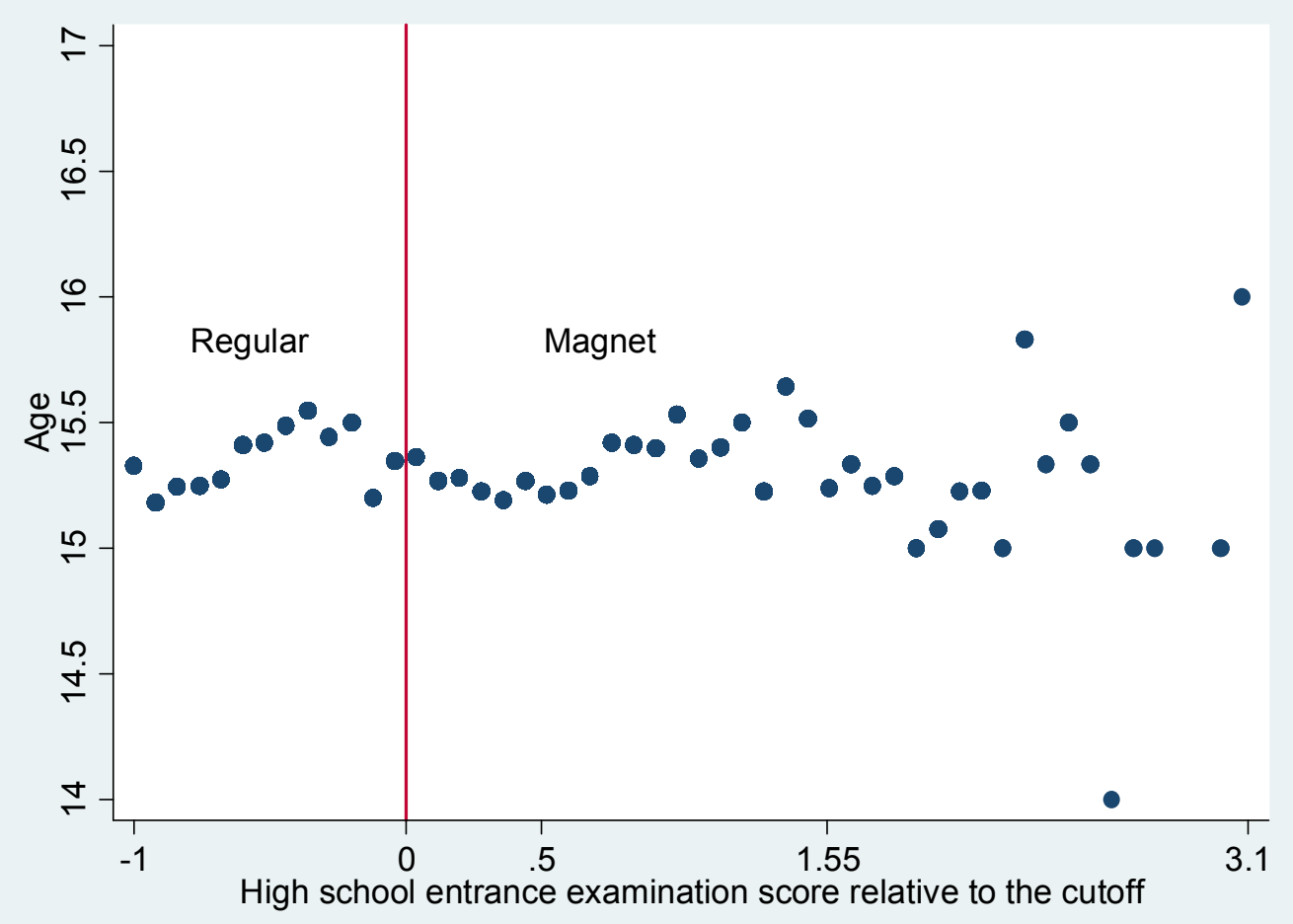


Panel C Middle school quality

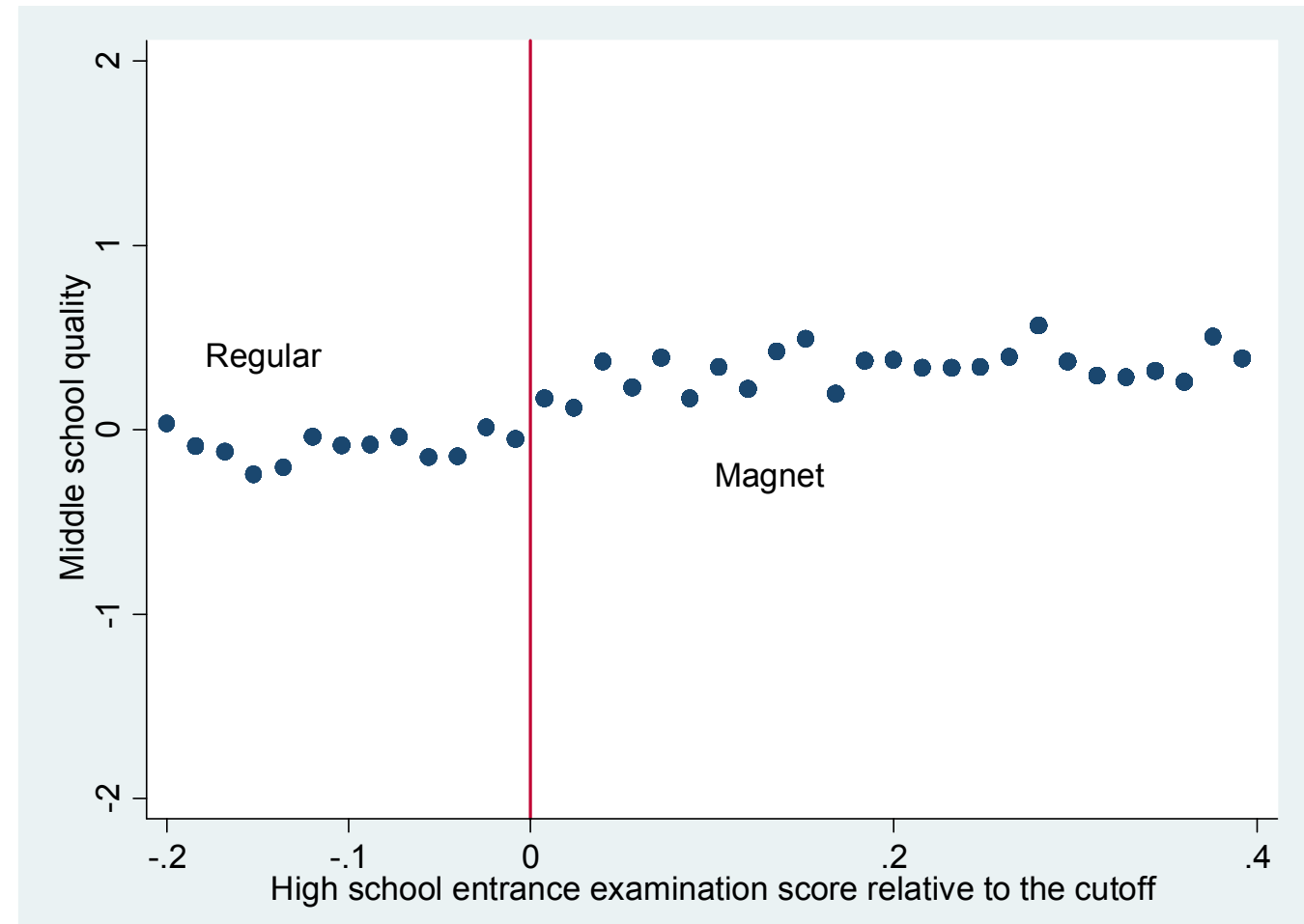

Note: (1) Middle school quality for a student is measured by average high school entrance examination score of students attending the same middle school in the same year. (2) Dots in Panel A are the mean values of female dummy for students having high school entrance examination score (relative to the cutoff) in equidistant bins with the width equal to 0.08 . Dots in Panel B are the mean values of age for students having high school entrance examination score (relative to the cutoff) in equidistant bins with the width equal to 0.08 . Dots in Panel $\mathrm{C}$ are the mean values of the middle school quality measurement for students having high school entrance examination score (relative to the cutoff) in equidistant bins with the width equal to 0.016 . The dots are plotted against the midpoint of each bin.

(3) The bandwidth of the neighborhood around the cutoff line in each figure is consistent with that used for the corresponding outcome variable in Table 4, which is chosen by the cross-validation method. 
Figure 3 Effects of attending magnet high schools

Panel A College entrance examination score

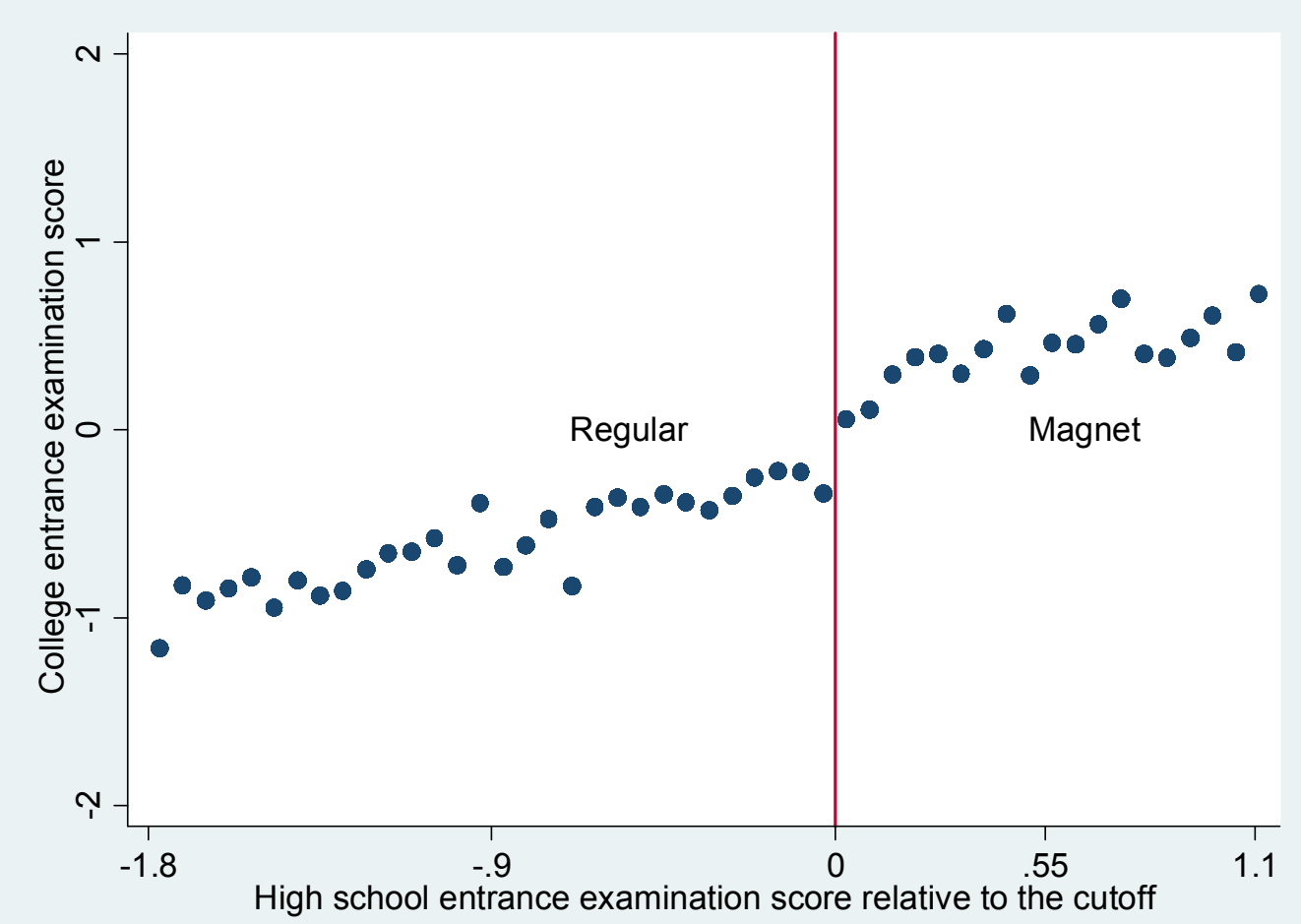

Panel B College eligibility

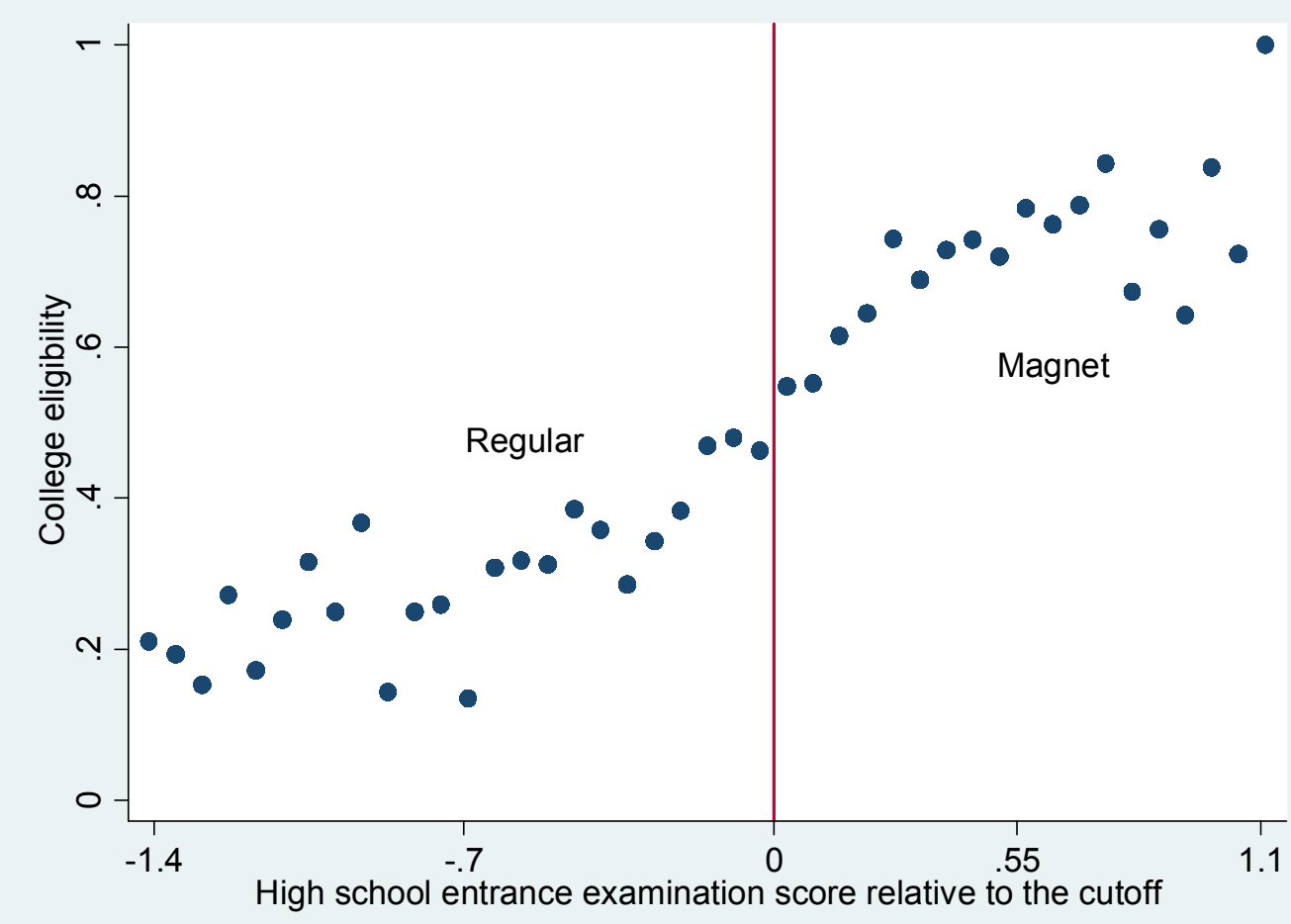


Note: (1) Dots in Panel A are the mean values of college entrance examination score for students having high school entrance examination score (relative to the cutoff) in equidistant bins with the width equal to 0.06. Dots in Panel B are share of students qualifying for college for students having high school entrance examination score (relative to the cutoff) in equidistant bins with the width equal to 0.06 . The dots are plotted against the midpoint of each bin.

(2) The bandwidth of the neighborhood around the cutoff line in each figure is consistent with that used for the corresponding outcome variable in Table 5, which is chosen by the cross-validation method. 
Table 1 Different characteristics between magnet schools and regular schools

\begin{tabular}{|c|c|c|c|c|c|c|c|}
\hline & (1) & $(2)$ & (3) & (4) & (5) & (6) & (7) \\
\hline & $\begin{array}{l}\text { Ratio of } \\
\text { teachers } \\
\text { having } \\
\text { advanced } \\
\text { title }\end{array}$ & $\begin{array}{l}\text { Ratio of } \\
\text { teachers having } \\
\text { education of } \\
\text { four year } \\
\text { college }\end{array}$ & $\begin{array}{l}\text { Class } \\
\text { size }\end{array}$ & $\begin{array}{l}\text { No. of } \\
\text { students }\end{array}$ & $\begin{array}{l}\text { Campus } \\
\text { area } \\
(10000 \\
\text { square } \\
\text { meters })\end{array}$ & $\begin{array}{l}\text { No. of } \\
\text { books in } \\
\text { library } \\
\text { (10000 } \\
\text { units) }\end{array}$ & $\begin{array}{l}\text { Does } \\
\text { equipment } \\
\text { satisfy } \\
\text { criteria }\end{array}$ \\
\hline \multirow{2}{*}{$\begin{array}{l}\text { Magnet } \\
\text { school=1 }\end{array}$} & 0.101 & 0.424 & 8.883 & 851.773 & 5.171 & 6.772 & 0.526 \\
\hline & $(0.047)^{* *}$ & $(0.094)^{* * *}$ & $(4.524)^{*}$ & $(166.235)^{* * *}$ & $(0.693)^{* * *}$ & $(1.070) * * *$ & $(0.191)^{* *}$ \\
\hline Observations & 57 & 55 & 58 & 55 & 51 & 46 & 43 \\
\hline Regular school & 0.074 & 0.341 & 52.814 & 767.803 & 2.523 & 0.660 & 0.324 \\
\hline
\end{tabular}

Robust standard errors in parentheses; * significant at $10 \%$; ** significant at 5\%; *** significant at $1 \%$

Note:

(1) All regressions include county-year fixed effects.

(2) The row of "Regular school" shows the mean values of the dependent variables for regular schools. 
Table 2. Summary statistics

\begin{tabular}{lccc}
\hline Variable & Mean & S.D. & Observation \\
Female & 0.359 & 0.480 & 5373 \\
Age & 15.315 & 0.678 & 5373 \\
High school entrance examination score & 0.098 & 0.957 & 5373 \\
Magnet & 0.535 & 0.499 & 5373 \\
Eligible & 0.531 & 0.499 & 5373 \\
Taking liberal arts track & 0.295 & 0.456 & 5373 \\
College entrance examination score & -0.085 & 1.035 & 5373 \\
Eligible for college & 0.497 & 0.500 & 5373 \\
\hline Note:
\end{tabular}

Note:

(1) Magnet is a dummy variable with one representing attending magnet high school and zero otherwise. Eligible is also a dummy variable with one representing having high school entrance examination scores equal to or higher than the cutoff line of magnet high school and zero otherwise. The definitions apply to all other tables. 
Table 3. Determinants of attending a magnet school

Dependent variable: Magnet

Eligible

$\begin{array}{cc}0.517 & 0.331 \\ (0.027)^{* * *} & (0.040)^{* * *}\end{array}$

Female

Age

Bandwidth used

$[-2,2]$

Observations

4986

0.60

$[-2,2]$

R-squared

261.28

4986

IV validity (F-value)

0.61

0.385

$\begin{array}{cc}(0.026) * * * & (0.028)^{* * *} \\ 0.019 & 0.021 \\ (0.010)^{*} & (0.010)^{* *} \\ -0.040 & -0.039 \\ (0.010)^{* * *} & (0.010)^{* * *}\end{array}$

Standard errors in parentheses are calculated by clustering over county-high school entrance examination score.

* significant at $10 \%$;* significant at $5 \%$; *** significant at $1 \%$

Note:

(1) In columns 3 and 4, we control for the county-year fixed effects, and middle school fixed effects.

(2) In columns 1, 3 and 4, a first order polynomial function of students' high school entrance examination score relative to the cutoff is controlled, respectively. In column 2, a second order polynomial function of students' high school entrance examination score relative to the cutoff is controlled.

(3) Bandwidth used in columns 1 and 2 is consistent with that used in Figure 1. Bandwidth in column 3 is consistent with that used in columns 1-3 in Table 5. Bandwidth in column 4 is consistent with that used in columns 4-6 in Table 5. 
Table 4 Covariate continuity tests

(1)

(2)

(3)

(4)

(5)

Female $=1 \quad$ Female $=1$

Age

Age

Middle school

quality

$-0.031$

Eligible

$-0.009$

(0.028)

$(0.039)$

Magnet(Eligible as IV)

$-0.023$

$(0.068)$

Female $=1$

Age

$-0.049 \quad-0.050$

$(0.014)^{* * *} \quad(0.014)^{* * *}$

Bandwidth used

$[-2.5,1] \quad[-2.5,1]$

Observations

4648

4648

0.05

0.092

(0.056)

$-0.092$

$(0.119)$

(0.056)

$-0.048 \quad-0.046$

$(0.019)^{* *}(0.019)^{* *}$

0.040

0.037

$(0.026)$

$(0.025)$

0.010

0.024

$(0.014)$
$[-0.2,0.4]$

$(0.021)$

R-squared

0.05

$[-1,3.1] \quad[-1,3.1]$

$[-0.2,0.4]$

1388

1388

Standard errors in parentheses are calculated by clustering over county-high school entrance examination score.

$*$ significant at $10 \% ; * *$ significant at $5 \% ; * * *$ significant at $1 \%$

Note:

(1) Middle school quality for a student is measured by the average high school entrance examination score of students attending the same middle school in the same year.

(2) In all columns, we control for a first order polynomial function of students' high school entrance examination scores relative to the cutoff, and county-year fixed effects. In columns 1 to 4, we also control for middle school fixed effects.

(3) The bandwidths used in this table are chosen by the cross-validation method for outcome variables, respectively. 
Table 5 Effects of school quality on students' college entrance examination score and college eligibility

$\begin{array}{lllll}(1) & \text { (2) } & \text { (3) } & \text { (4) } & \text { (5) }\end{array}$

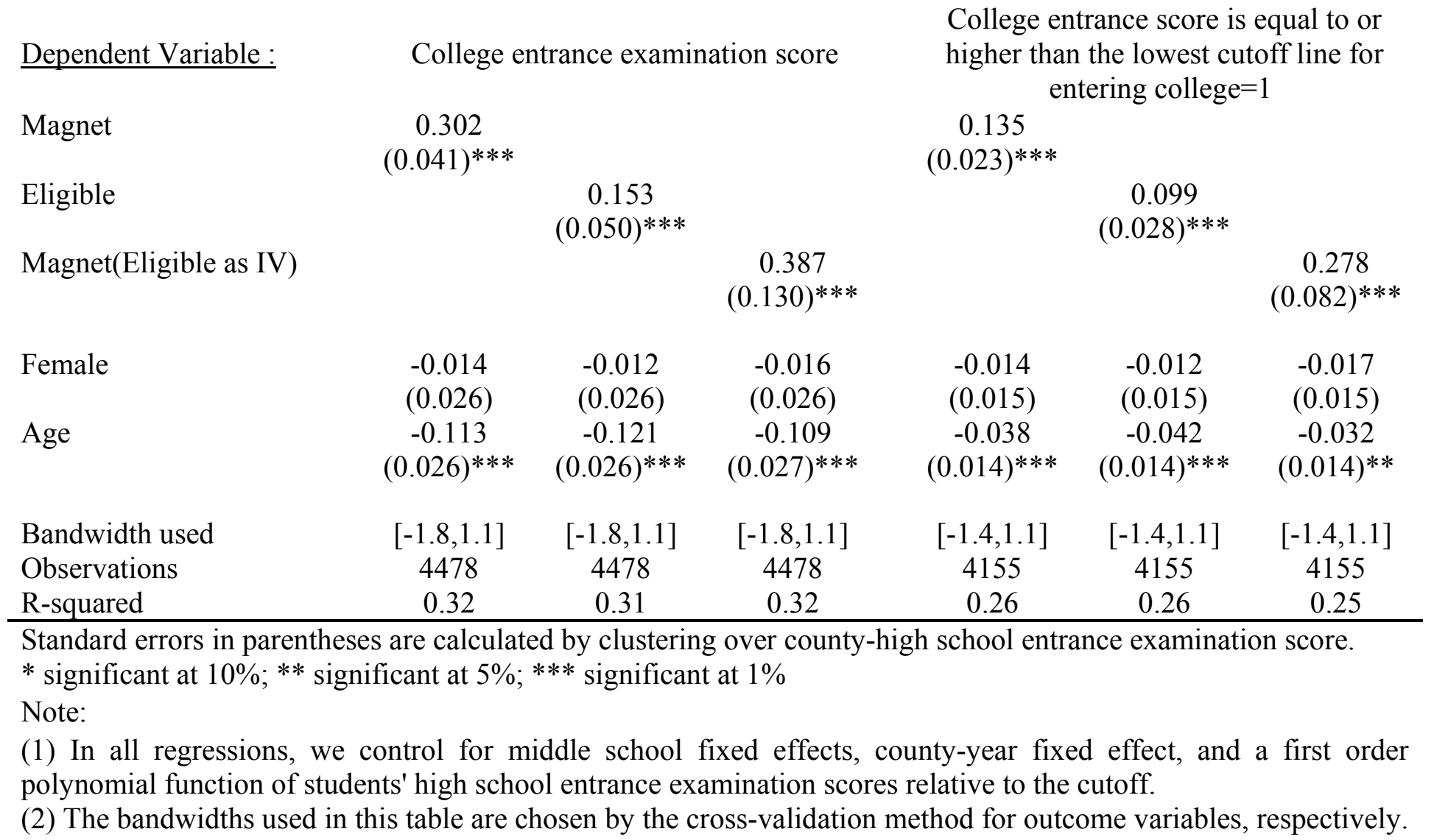


Table 6 Heterogeneity tests

(1)

$$
\text { (2) }
$$

College entrance

score is equal to or

College entrance

examination score

higher than the

lowest cutoff line

for entering

college $=1$

$0.003 \quad 0.074$

(0.072)

Magnet*Age

(Eligible*Age as IV)

Magnet (Eligible as IV)

Female

Age

Bandwidth used

Observations

R-squared

(0.049)
(3)

College entrance examination

score

Standard errors in parentheses are calculated by clustering over county-high school entrance examination score.

* significant at $10 \%$; * significant at $5 \%$; ** significant at $1 \%$

Note:

(1) In all regressions, we control for middle school fixed effects, county-year fixed effects, and a first order polynomial function of students' high school entrance examination score relative to the cutoff.

(2) Bandwidth used in columns 1 and 3 is consistent with that used in columns 1-3 in Table 5. Bandwidth used in columns 2 and 4 is consistent with that used in columns 4-6 in Table 5.
College entrance

score is equal to or higher than the

lowest cutoff line for entering college $=1$
$(0.566)$

$-0.017$

(0.016)

$-0.024$

(0.027)

$[-1.4,1.1]$

4155

0.25 
Table 7 Determinants of observing a college entrance examination score

(3)

Dependent Variable : Having a college entrance examination score $=1$

$\begin{array}{lccc}\text { Magnet(Eligible as IV) } & -0.022 & -0.020 & -0.039 \\ & (0.045) & (0.051) & (0.042) \\ \text { Female } & -0.069 & -0.069 & -0.072 \\ & (0.010)^{* * *} & (0.011)^{* * *} & (0.010)^{* * *} \\ \text { Age } & -0.012 & -0.012 & -0.008 \\ & (0.007)^{*} & (0.007)^{*} & (0.007) \\ & & & \\ \text { Bandwidth used } & {[-1.8,1.1]} & {[-1.4,1.1]} & {[-1.5,2.4]} \\ \text { Observations } & 7032 & 6331 & 7202 \\ \text { R-squared } & 0.30 & 0.29 & 0.28\end{array}$

Standard errors in parentheses are calculated by clustering over county-high school entrance examination score.

* significant at $10 \% ; *$ significant at $5 \% ; * * *$ significant at $1 \%$

Note:

(1) In all regressions, we control for middle school fixed effects, county-year fixed effects, and a first order polynomial function of students' high school entrance examination score relative to the cutoff.

(2) Bandwidth in column 1 is consistent with that used in columns 1-3 in Table 5. Bandwidth in column 2 is consistent with that used in columns 4-6 in Table 5. Bandwidth in column 3 is chosen by the cross-validation method for the dependent variable. 
Table 8 Effects of entering a magnet school on students' course study

(1) (2)

(3)

Dependent Variable : Taking literal arts track $=1$, taking other tracks $=0$

Magnet(Eligible as IV)

$\begin{array}{lll}-0.081 & -0.087 & -0.068 \\ (0.071) & (0.081) & (0.076)\end{array}$

Female

0.135

0.134

0.111

Age

$$
(0.015) * * *
$$

0.010

$(0.015)^{* * *}$

$(0.015)^{* * *}$

$(0.013)$

0.009

0.009

14

Bandwidth used

$$
[-1.8,1.1]
$$$$
\text { (0.014) }
$$

Observations

Standard errors in parentheses are calculated by clustering over county-high school entrance examination score.

* significant at $10 \%$; * significant at 5\%; *** significant at $1 \%$ Note:

(1) In all regressions, we control for the middle school fixed effects, countyyear fixed effects, and a first order polynomial function of students' high school entrance examination scores relative to the cutoff.

(2) Bandwidth used in column 1 is consistent with that used in columns 1-3 in Table 5. Bandwidth used in column 2 is consistent with that used in columns 4-6 in Table 5. Bandwidth used in column 3 is chosen by the method of cross-validation for the dependent variable. 
Table 9 Robustness of main results to the bandwidth used 
Table 10 Total effects of entering good school on the probability to enter college

\begin{tabular}{|c|c|c|c|}
\hline Magnet(Eligible as IV) & $\begin{array}{c}(1) \\
0.227 \\
(0.053)^{* * *}\end{array}$ & $\begin{array}{c}(2) \\
0.217 \\
(0.062)^{* * *}\end{array}$ & $\begin{array}{c}(3) \\
0.217 \\
(0.073)^{* * *}\end{array}$ \\
\hline Female & $\begin{array}{c}-0.041 \\
(0.010)^{* * *}\end{array}$ & $\begin{array}{c}-0.045 \\
(0.011)^{* * *}\end{array}$ & $\begin{array}{c}-0.042 \\
(0.012)^{* * *}\end{array}$ \\
\hline Age & $\begin{array}{c}-0.032 \\
(0.012)^{* * *}\end{array}$ & $\begin{array}{c}-0.037 \\
(0.013)^{* * *}\end{array}$ & $\begin{array}{c}-0.043 \\
(0.014)^{* * *}\end{array}$ \\
\hline $\begin{array}{l}\text { Bandwidth used } \\
\text { Observations } \\
\text { R-squared }\end{array}$ & $\begin{array}{c}{[-1.8,1.1]} \\
7032 \\
0.21 \\
\end{array}$ & $\begin{array}{c}{[-1.4,1.1]} \\
6331 \\
0.19 \\
\end{array}$ & $\begin{array}{c}{[-1.2,1]} \\
5765 \\
0.18 \\
\end{array}$ \\
\hline \multicolumn{4}{|c|}{$\begin{array}{l}\text { Standard errors in parentheses are calculated by clustering over county-high school entrance } \\
\text { exam score. } \\
\text { * significant at } 10 \% \text {; }{ }^{*} \text { significant at } 5 \% \text {; } * * \text { significant at } 1 \% \\
\text { Note: } \\
\text { (1) The dependent variable is an indicator. It is equal to } 1 \text { if the student's college entrance } \\
\text { examination score is equal to or higher than the lowest cutoff line for entering the college, } \\
\text { and it is equal to } 0 \text { if the student's college entrance examination score is lower than the cutoff } \\
\text { line or the student does not have a college entrance examination score. In other words, } \\
\text { students having missing college entrance examination scores are assumed not to be eligible } \\
\text { for colleges. } \\
\text { (2) In all regressions, we control for middle school fixed effects, county-year fixed effects, } \\
\text { and a first order polynomial function of students' high school entrance examination score } \\
\text { relative to the cutoff. } \\
\text { (3) Bandwidth used in column } 1 \text { is consistent with that used in columns } 1-3 \text { in Table } 5 \text {. } \\
\text { Bandwidth used in column } 2 \text { is consistent with that used in columns } 4-6 \text { in Table } 5 \text {. } \\
\text { Bandwidth used in column } 3 \text { is chosen by the cross-validation method for the dependent } \\
\text { variable. }\end{array}$} \\
\hline
\end{tabular}


Appendix Table 1 Difference of the difference between magnet and regular schools

\begin{tabular}{|c|c|c|c|c|c|c|c|}
\hline & (1) & $(2)$ & (3) & (4) & (5) & (6) & (7) \\
\hline & $\begin{array}{l}\text { Ratio of } \\
\text { teachers } \\
\text { having } \\
\text { advanced } \\
\text { title }\end{array}$ & $\begin{array}{c}\text { Ratio of } \\
\text { teachers } \\
\text { having } \\
\text { education of } \\
\text { four year } \\
\text { college }\end{array}$ & $\begin{array}{l}\text { Class } \\
\text { size }\end{array}$ & $\begin{array}{l}\text { No. of } \\
\text { students }\end{array}$ & $\begin{array}{l}\text { Campus } \\
\text { area } \\
(10000 \\
\text { square } \\
\text { meters })\end{array}$ & $\begin{array}{l}\text { No. of } \\
\text { books in } \\
\text { library } \\
\text { (10000 } \\
\text { units) }\end{array}$ & $\begin{array}{c}\text { Does } \\
\text { equipment } \\
\text { satisfy } \\
\text { criteria }\end{array}$ \\
\hline \multicolumn{8}{|l|}{ Magnet school=1 } \\
\hline \multirow{2}{*}{$\begin{array}{l}* \text { County having binding } \\
\text { cutoff line }=1\end{array}$} & 0.019 & 0.178 & -0.318 & -82.672 & 2.632 & 5.350 & -0.035 \\
\hline & $(0.080)$ & $(0.154)$ & $(6.248)$ & $(371.810)$ & $(2.920)$ & $(4.464)$ & $(0.393)$ \\
\hline \multirow[t]{2}{*}{ Magnet school=1 } & 0.083 & 0.246 & 9.201 & 934.446 & 2.538 & 1.422 & 0.562 \\
\hline & $(0.021)^{* * *}$ & $(0.047)^{* * *}$ & $(5.619)$ & $(323.279)^{* *}$ & $(0.608)^{* * *}$ & $(1.072)$ & $(0.360)$ \\
\hline County-year fixed effect & Yes & Yes & Yes & Yes & Yes & Yes & Yes \\
\hline Observations & 103 & 99 & 94 & 99 & 95 & 91 & 80 \\
\hline R-squared & 0.24 & 0.43 & 0.37 & 0.58 & 0.72 & 0.63 & 0.57 \\
\hline
\end{tabular}

Robust standard errors are in parentheses

$*$ significant at $10 \% ; * *$ significant at $5 \% ; * * *$ significant at $1 \%$ 